HEALTH MATTERS 



\section{Health Matters}

Evidence, Critical Social Science, and Health Care in Canada

EDITED BY ERIC MYKHALOVSKIY, JACOUELINE CHOINIERE, PAT ARMSTRONG, AND HUGH ARMSTRONG

UNIVERSITY OF TORONTO PRESS

Toronto Buffalo London 
(C) University of Toronto Press 2020

Toronto Buffalo London

utorontopress.com

Printed in the U.S.A.

ISBN 978-1-4875-0779-4 (cloth)

ISBN 978-1-4875-3697-8 (EPUB)

ISBN 978-1-4875-2538-5 (paper)

ISBN 978-1-4875-3696-1 (PDF)

\section{Library and Archives Canada Cataloguing in Publication}

Title: Health matters : evidence, critical social science, and health care in

Canada / edited by Eric Mykhalovskiy, Jacqueline Choiniere, Pat Armstrong, and Hugh Armstrong.

Other titles: Health matters (2020)

Names: Mykhalovskiy, Eric, editor. | Choiniere, Jacqueline, 1952- editor. |

Armstrong, Pat, 1945- editor. | Armstrong, Hugh, 1943- editor.

Description: Includes bibliographical references and index.

Identifiers: Canadiana (print) 20200192108 | Canadiana (ebook) 20200192124 |

ISBN 9781487507794 (cloth) | ISBN 9781487525385 (paper)|

ISBN 9781487536978 (EPUB) | ISBN 9781487536961 (PDF)

Subjects: LCSH: Social medicine - Canada. | LCSH: Medical care - Research -

Canada. | LCSH: Medical care - Canada - Evaluation. | LCSH:

Evidence-based medicine - Canada. | LCSH: Medical policy - Canada.

Classification: LCC RA418.3.C3 H43 2020 | DDC 362.1/0420971 - dc23

This book has been published with the help of a grant from the Federation for the Humanities and Social Sciences, through the Awards to Scholarly Publications Program, using funds provided by the Social Sciences and Humanities Research Council of Canada.

University of Toronto Press acknowledges the financial assistance to its publishing program of the Canada Council for the Arts and the Ontario Arts Council, an agency of the Government of Ontario.
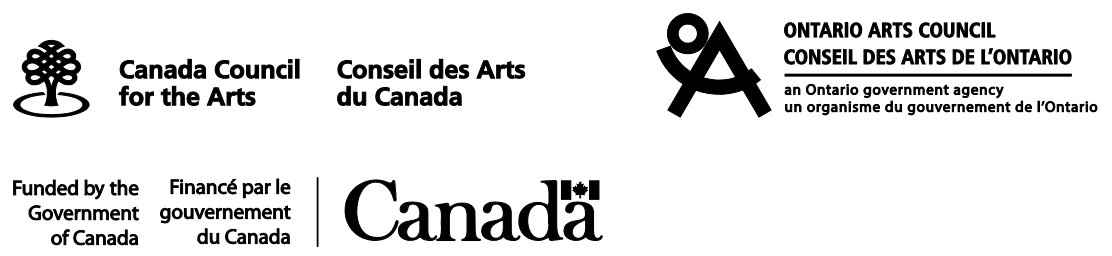